\title{
In vitro studies of biowastes on growth and sporulation of fungal bioagents
}

\author{
Mucksood Ahmad Ganaie* and Tabreiz Ahmad Khan
}

Section of Plant Pathology and Nematology, Department of Botany, Aligarh Muslim University, Aligarh, India.

Accepted 21 August, 2013

\begin{abstract}
Biowastes of mango, carrot, papaya, banana, chukandar, pomegranate, orange, mosambi, chickpea and wheat were used to study the colony formation and sporulation of Trichoderma harzianum and Paecilomyces lilacinus. In the present study, it was observed that the initiation of colony formation of the fungal bioagents was recorded after $12 \mathrm{~h}$ only in biowaste of carrot, mango, chukandar, banana and papaya. In general, the growth of colony formation increased with the increase in duration. The whole diameter of Petri dish was occupied by fungal mycelium after $120 \mathrm{~h}$ in the biowaste of carrot, mango, chukandar, banana, and papaya. Further, it was observed that the maximum number of spores $/ \mathrm{ml}$ of $T$. harzianum were obtained on biowaste of carrot followed by mango, chukandar, banana, papaya, orange, mosambi, gram, pomegranate and wheat. Similarly, in case of $\boldsymbol{P}$. lilacinus, the highest numbers of spores were recorded on biowaste of mango followed by carrot, papaya, banana, chukandar, orange, mosambi, gram, pomegranate and wheat. Evaluation of sporulation of $T$. harzianum and $P$. lilacinus on different biowastes revealed that the tested fungi showed significant increase in sporulation on biowastes of mango, carrot, banana, papaya and chukandar as compared to control (Potato Dextrose Agar [PDA]). However, on the other hand, significant reduction in fungal sporulation was observed on biowastes of orange, mosambi, pomegranate, gram and wheat as compared to control.
\end{abstract}

Key words: Biowaste, Trichoderma harzianum, Paecilomyces lilacinus, fungal sporulation, mycellial growth.

\section{INTRODUCTION}

During the last few decades fruits have attracted the attention of biologists not only because of their nutritive value but also their use in mass multiplication of bioagents (Zaki and Bhatti, 1991; Tewari and Bhanu, 2003). Biowastes of different fruits are used as bioagents either directly or indirectly. Greater emphasis has been given to biological control of plant parasitic nematodes through the use of nematode parasitic fungi Paecilomyces lilacinus (Morgan-Jones et al., 1981; Jatala, 1985; Khan and Saxena, 1996; Anver and Alam, 1998). P. lilacinus is a common soil hyphomycete with a worldwide distribution, parasitizes eggs of Meloidogyne incognita. The fungus has been used as bioagent for the management of plant parasitic nematodes. Similarly, research has been done on the biocontrol nature of Trichoderma species (Papavizas, 1985; Chet, 1987) of these $T$. harzianum showed highest potential against many soil born fungal pathogens. $T$. harzianum have been known to suppress many soil born fungi. It has been found to antagonize fungal plant pathogens as well as plant parasitic nematodes (Siddiqui et al., 1999).

Since, $P$. lilacinus and Trichoderma harzianum are important bioagents against plant parasitic nematodes and fungal pathogens. Mass production of these fungi is an important prerequisite for any large scale field application. Our emphasis in the present study was to 
Table 1. Effect of different Bio-wastes on mycellial growth and sporulation of Paecilomyces lilacinus at different intervals.

\begin{tabular}{|c|c|c|c|c|c|c|c|c|}
\hline \multirow{2}{*}{ Bio- waste used } & \multicolumn{6}{|c|}{ Diameter of mycelia growth $(\mathrm{cm})$ after $(\mathrm{h})$} & \multirow{2}{*}{${ }^{*}$ Spores $/ \mathrm{ml}$} & \multirow{2}{*}{$\begin{array}{l}\text { Percentage increase or } \\
\text { decrease over control }\end{array}$} \\
\hline & 12 & 24 & 48 & 72 & 96 & 120 & & \\
\hline Mango & 0.5 & 2.0 & 4.2 & 7.4 & 9.5 & 10 & $3.30 \times 10^{7 a}$ & +68.36 \\
\hline carrot & 0.4 & 1.8 & 4.0 & 6.9 & 9.2 & 10 & $3.16 \times 10^{7 a}$ & +62.22 \\
\hline Wheat & 0.3 & 1.7 & 3.8 & 6.7 & 8.9 & 10 & $2.97 \times 10^{7 \mathrm{~b}}$ & +32 \\
\hline Banana & 0.2 & 1.7 & 3.5 & 6.5 & 8.6 & 10 & $2.54 \times 10^{7 \mathrm{c}}$ & +14 \\
\hline Chukander & 0.2 & 1.6 & 3.3 & 6.5 & 8.4 & 10 & $2.50 \times 107^{\mathrm{C}}$ & +12 \\
\hline Papaya & 0.0 & 1.3 & 2.5 & 5.4 & 7.4 & 8.1 & $2.33 \times 10^{7 e}$ & -16 \\
\hline Mosambi & 0.0 & 1.2 & 2.4 & 5.2 & 7.4 & 8.0 & $2.15 \times 10^{7 e}$ & -26 \\
\hline Gram & 0.0 & 1.2 & 2.3 & 3.7 & 4.5 & 7.6 & $0.97 \times 10^{7 f}$ & -50 \\
\hline Pomegranate & 0.0 & 0.8 & 1.4 & 2.9 & 4.3 & 6.7 & $0.92 \times 10^{7 f}$ & -53 \\
\hline Orange & 0.0 & 0.6 & 1.3 & 2.7 & 4.2 & 5.8 & $0.68 \times 10^{7 g}$ & -65 \\
\hline PDA & 0.2 & 1.5 & 3.1 & 6.5 & 7.5 & 9.6 & $1.96 \times 10^{7 d}$ & \\
\hline LSD at $5 \%$ & & & & & & 2.08 & & \\
\hline LSD at $1 \%$ & & & & & & 2.82 & & \\
\hline
\end{tabular}

*Values with same alphabetical letters are non significant, while values with different letters are significant according to data analysis by SPSS version 16.

find out the highly productive, cost effective and locally available biowastes for mass multiplication of bioagents viz., P. lilacinus and T. harzianum.

\section{MATERIALS AND METHODS}

Locally available fresh biowastes of mango, carrot, papaya, banana, chukandar, orange, mosambi, and pomegranate were obtained from fruit juice shop. In addition to the above, gram husk and wheat bran were also taken to evaluate the mass multiplication of the tested fungus viz. T. harzianum and $P$. lilacinus. The pericarp of selected biowastes viz., mango, carrot, papaya, banana, chukandar, orange, mosambi, and pomegranate were cut into small pieces with the help of electric grinder. Ten grams of each biowaste was taken and spread on Petri plate. Biowaste of gram husk and wheat bran were moistened with distilled water before spreading on Petri plates. These Petri plates with different biowastes were autoclaved at $20 \mathrm{lbs}$ for about $15 \mathrm{~min}$. After sterilization, each Petri plate was inoculated with $1 \mathrm{ml}$ of spore suspension prepared from 15 days old culture of $P$. lilacinus and $T$. harzianum grown on potato dextrose agar (PDA). Each set of biowaste was replicated three times. The inoculated Petri plates were kept in biochemical oxygen demand (BOD) incubator at $28 \pm 1^{\circ} \mathrm{C}$. The Petri plates were observed at different intervals to observe the colony growth of fungal bioagents viz., $T$. harzianum and $P$. lilacinus on different biowastes. The spore suspension of each sample was prepared by dispersing $1 \mathrm{~g}$ of each inoculum in $10 \mathrm{ml}$ distilled water and spores were counted by using a haemocytometer.

\section{RESULTS AND DISCUSSION}

The results of the present study revealed that both the fungi grew profusely on some of the tested biowastes. The highest spore count in case of $P$. lilacinus was recorded on biowaste of mango $\left(3.30 \times 10^{7}\right)$ followed by carrot $\left(3.16 \times 10^{7}\right)$, papaya $\left(2.60 \times 10^{7}\right)$, banana $\left(2.1 \times 10^{7}\right)$ and chukandar $\left(2.1 \times 10^{7}\right)$. The fungus $P$. lilacinus has also been previously grown on different fruit grains (Zaki and Bhatti, 1991) and other agro industrial wastes (Leena et al., 2003). P. lilacinus is an important fungal biocontrol agent and has been reported to be effective in controlling plant parasitic nematodes in different crops (Jatala, 1986; Nagesh and Parvatha Reddy, 2003; Ashraf et al., 2005). Similarly in case of $T$. harzianum, the maximum spore count was observed on biowaste of carrot $\left(3.14 \times 10^{7}\right)$ followed by mango $\left(3.07 \times 10^{7}\right)$, chukandar $\left(2.97 \times 10^{7}\right)$, banana $\left(2.94 \times 10^{7}\right)$ and papaya $\left(2.86 \times 10^{7}\right)$. The high spore count of the tested fungi on these biowastes may be possibly due to high carbohydrate content in them. However, in case of both tested fungi, the lower spore count was observed on biowastes of orange, mosambi, pomegranate, gram and wheat in comparison with control (PDA). The lower spore count on these biowastes might be due to the inhibitory effect of some chemicals and/or lower carbohydrate content present in these biowastes.

Furthermore, significant increase in spore count of $P$. lilacinus was observed on biowaste of mango $(+68.36 \%)$ followed by carrot $(+62.22 \%)$, papaya $(+32 \%)$, banana $(+14 \%)$ and chukandar $(+12 \%)$. A significant decrease in spore count of $P$. lilacinus was observed on biowaste of wheat $(-65 \%)$ followed by pomegranate $(-53 \%)$, gram ($50 \%)$, mosambi $(-26 \%)$ and orange $(-16 \%)$. In case of $T$. harzianum, significant increase in spore count was observed on biowaste of carrot $(+67 \%)$ followed by mango $(+64 \%)$, chukandar $(+52 \%)$, banana $(+44 \%)$ and papaya $(+41 \%)$ and significant decrease in spore count of T. harzianum was observed on biowaste of wheat $(-77 \%)$ followed by pomegranate $(-68 \%)$, gram $(-58 \%)$, mosambi $(-40 \%)$ and orange $(-35 \%)$.

The data presented in Tables 1 and 2 reveal that, in general mycellial growth of both tested fungi on different biowastes increased with increase in incubation period. 
Table 2. Effect of different Bio-wastes on mycellial growth and sporulation of Trichoderma harzanium at different intervals.

\begin{tabular}{lcccccccc}
\hline \multirow{2}{*}{ Bio-waste used } & \multicolumn{9}{c}{ Diameter of mycelia growth $(\mathbf{c m})$ after $(\mathbf{h})$} & \multirow{2}{*}{ *Spores/ml } & $\begin{array}{c}\text { Percentage increase or } \\
\text { decrease over control }\end{array}$ \\
\cline { 2 - 6 } & $\mathbf{1 2}$ & $\mathbf{2 4}$ & $\mathbf{4 8}$ & $\mathbf{7 2}$ & $\mathbf{9 6}$ & $\mathbf{1 2 0}$ & & +67 \\
Wheat & 0.4 & 2.0 & 4.3 & 6.2 & 8.2 & 10 & $3.64 \times 10^{7 \mathrm{a}}$ & +64 \\
Mango & 0.4 & 1.7 & 3.6 & 6.7 & 8.3 & 10 & $3.62 \times 10^{7 \mathrm{a}}$ & +52 \\
Chukandar & 0.3 & 1.7 & 3.4 & 6.2 & 7.8 & 10 & $3.50 \times 10^{7 \mathrm{a}, \mathrm{b}}$ & +44 \\
Banana & 0.2 & 1.6 & 3.5 & 6.4 & 7.7 & 10 & $2.71 \times 10^{7 \mathrm{~b}}$ & +41 \\
Papaya & 0.2 & 1.5 & 2.7 & 5.8 & 6.9 & 10 & $2.65 \times 10^{7 \mathrm{~b}}$ & -35 \\
Carrot & 0.0 & 1.3 & 2.5 & 3.2 & 5.6 & 8.6 & $2.61 \times 10^{7 \mathrm{~d}}$ & -40 \\
Mosambi & 0.0 & 1.0 & 1.6 & 2.5 & 4.7 & 7.7 & $1.95 \times 10^{7 \mathrm{~d}}$ & -58 \\
Gram & 0.0 & 1.0 & 1.3 & 2.4 & 4.6 & 7.2 & $1.38 \times 10^{7 \mathrm{e}}$ & -68 \\
Pomegranate & 0.0 & 0.6 & 1.2 & 2.5 & 3.2 & 5.8 & $1.20 \times 107^{\mathrm{e}, \mathrm{f}}$ & -77 \\
Orange & 0.0 & 0.5 & 1.1 & 2.3 & 3.1 & 5.2 & $0.92 \times 10^{7 \mathrm{f}}$ & \\
PDA & 0.3 & 1.6 & 3.4 & 6.5 & 7.6 & 9.4 & $1.87 \times 10^{7 \mathrm{c}}$ & \\
LSD at 5\% & & & & & & 2.02 & & \\
LSD at 1\% & & & & & & 2.74 & & \\
\hline
\end{tabular}

*Values with same alphabetical letters are non significant, while values with different letters are significant according to data analysis by SPSS version 16 .

The colony morphology of all the isolates was more or less similar showing spare to thin cottony mycellial mass. These results also support the earlier findings made by Rifai (1969), Domsch et al. (1980), Martha (1992) and Mazumdar (1993). Initiation of sporulation was observed after $12 \mathrm{~h}$ on biowastes of mango, carrot, papaya, banana and chukandar for both tested fungi whereas for the rest of biowastes initiation of sporulation was observed after $48 \mathrm{~h}$.

The present study concludes that biowastes of mango, carrot, papaya, banana and chukandar are efficient for the mass multiplication of bioagents viz., $T$. harzianum and $P$. lilacinus as compared to control (PDA). Therefore, these biowastes may be used as supplements for the mass multiplication of these fungi. Elad et al. (1980) have reported the mixture of bran, saw dust and water as suitable substrates for mass multiplication of $T$. harzianum. Biowastes of pomegranate, orange, mosambi, gram and wheat although resulted in low sporulation may serve as substrate in combination with other nutrient rich supplements for mass multiplication of $T$. harzianum and $P$. lilacinus.

\section{REFRENCES}

Anver S, Alam MM (1998). Control of Meloidogyne incognita and Rotylenchus reniformis singly and concomitantly on pigeonpea with Paecilomyces lilacinus. Indian J. Nematol. 27(2):209-213.

Ashraf MS, Khan TA, Nisar S (2005). Integrated management of reniform nematode Rotylenchulus reniformis infecting okra by oil cakes and biocontrol agent Paecilomyces lilacinus. Pak. J. Nematol. 23:3005-309.

Domsch KH, Gams W, Anderson TH (1980). Trichoderma pers, ex. Fr. 1821. In compendium of soil Fungi, .1:368-77. Academic Press, N.Y.

Chet I (1987).Trichoderma: application, mode of action and potential as a biocontrol agent of soilborne plant pathogenic fungi, pp. 137-160.In
I. Chet (ed.), Innovative approaches to plant disease control. John Wiley \& Sons, New York.

Jatala P (1985). Biological control of nematode isn. :Sasser, J. N. \& Carter C. C. (Eds). An advanced treatise on Meloidogyne. Biology and Control. Raleigh, Department of Plant Pathology, North Carolina State University \& USAID. pp. 302-308.

Jatala P (1986). Biological control of plant parasitic nematodes. Ann. Rev. Phytopathol. 24:453-489.

Khan TA, Saxena SK (1996). Comparative efficacy of Paecilomyces lilacinus in the control of Meloidogyne Spp. And Rotylenchus reniformis on tomato. Pak. J. Nematol. 14(2):111-116.

Leena MD, Easwaramoorthy S, Nirmala R (2003). In vitro production of entomopathogenic fungi Paecilomyces farinosus (Hotmskiold) and Paecilomyces lilacinus (Thom) Samson using byproducts of sugar industry and other agro industrial byproducts and wastes. Sugar Tech. 5(4):231-236.

Martha PK (1992). Influence of some physic chemical factors on the germination and growth of biotype of Trichoderma harzianum and Gliocladium virens. M.Sc. dissertation. B.C.K.V., Mohanpur.

Mazumdar D (1993). Hyperparasitic potential of a few biotypes of $T$. harzianum and $G$. virens against two major pathogens of betelvine (Piper betle L.) M. Sc. Dissertation, B.C.K.V., Mohanpur.

Morgan-Jones G, Godoy, Rodriguez-Kabana R (1981). Verticillium chlamydosporium, fungal parasite of Meloidogyne arenaria females. Nematropica 11:115-120.

Nagesh M, Parvatha Reddy P (2003). Current trends in biological control of nematode pests in india. In: Nematode management of plants. Trivedi, P.C. (Ed.). Scientific Publishers, India, pp. 203-239.

Papavizas GC (1985). Trichoderma and Gliocladium their biology, ecology and potential of biocontrol. Ann. Rev. Phytopathol. 18:389 413.

Rifai MA (1969). A revision of the genus Trichoderma common W. Mycol. Inst. Mycol. 116:5-6.

Siddiqui IA, Ehteshamul-Haque S, Ghaffar A (1999). Root dip treatment with Pseudomonas aeruginosa and Trichoderma spp., in the control of root rot and root knot disease complex in chili (Capsicum annum L.). Pak. J. Nematol. 17:67-75.

Tewari L, Bhanu C (2003). Screening of various substrates for sporulation and mass multiplication of biocontrol agent Trichoderma harzianum through solid state fermentation. Indian Phytopathol. 56(4):476-478

Zaki FA, Bhatti DS (1991). Effect of culture media on sporulation of Paecilomyces lilacinus and its Efficacy against Meloidogyne javanica 
in tomato. Nematol. Medit. 19:211-212.

Elad Y, Chet I, Katan J (1980). Trichoderma harzianum a biocontrol agent of Sclerotium rolfsii and Rhizoctonia solani. Phytopathology 70:119-112. 